\title{
Real-Time Sensing of Hydrogen Peroxide by ITO/MWCNT/Horseradish Peroxidase Enzyme Electrode
}

\author{
Melinda Magyar, ${ }^{1,2}$ László Rinyu, ${ }^{3}$ Róbert Janovics, ${ }^{3}$ Péter Berki, ${ }^{4}$ Klára Hernádi, ${ }^{4}$ \\ Kata Hajdu, ${ }^{1}$ Tibor Szabó, ${ }^{1}$ and László Nagy ${ }^{1}$ \\ ${ }^{1}$ Department of Medical Physics and Informatics, University of Szeged, Rerrich B. tér 1, Szeged 6720, Hungary \\ ${ }^{2}$ Hungarian Academy of Sciences, Biological Research Centre Szeged, Institute of Plant Biology, Temesvári krt. 62, \\ Szeged 6726, Hungary \\ ${ }^{3}$ Hungarian Academy of Sciences, Institute for Nuclear Research, Hertelendi Laboratory of Environmental Studies, \\ Bem tér 18/c, Debrecen 4026, Hungary \\ ${ }^{4}$ Department of Applied and Environmental Chemistry, University of Szeged, Rerrich B. tér 1, Szeged 6720, Hungary
}

Correspondence should be addressed to Melinda Magyar; magyarmelu@gmail.com

Received 7 August 2016; Revised 23 October 2016; Accepted 24 October 2016

Academic Editor: Xuping Sun

Copyright (C) 2016 Melinda Magyar et al. This is an open access article distributed under the Creative Commons Attribution License, which permits unrestricted use, distribution, and reproduction in any medium, provided the original work is properly cited.

\begin{abstract}
The accurate and sensitive determination of $\mathrm{H}_{2} \mathrm{O}_{2}$ is very important in many cases because it is a product of reactions catalysed by several oxidase enzymes in living cells and it is essential in environmental and pharmaceutical analyses. The fabrication of enzyme protein activity based biosensors is a very promising way for this purpose because the function of biological molecules is very specific, sensitive, and selective. Horseradish peroxidase (HRP) is the most commonly used enzyme for $\mathrm{H}_{2} \mathrm{O}_{2}$ detection because it can oxidize hydrogen atoms and, for example, xenobiotics in the presence of $\mathrm{H}_{2} \mathrm{O}_{2}$. In order to define the limit of detection (LOD) of $\mathrm{H}_{2} \mathrm{O}_{2}$ we made calibrations with guaiacol and amplex red (AR), which are hydrogen donors of HRP. The accumulation of the reaction products, tetraguaiacol, and resorufin, respectively, then can be easily detected by absorption or emission (fluorescence) spectroscopy. In our experiments an enzyme electrode was fabricated from ITO (indium tin oxide), functionalized multiwalled carbon nanotubes (f-MWCNTs), and HRP. Although the enzyme activity was smaller by about two orders of magnitude when the enzyme was bound to the f-MWCNTs (ca. $10^{-2} \mathrm{M} \mathrm{H}_{2} \mathrm{O}_{2} /\left(\mathrm{MHRP} \cdot \mathrm{sec}\right.$ ) compared to ca. $2 \mathrm{M} \mathrm{H}_{2} \mathrm{O}_{2} /(\mathrm{M} \mathrm{HRP} \cdot \mathrm{sec}$ ) and $5 \mathrm{M} \mathrm{H}_{2} \mathrm{O}_{2} /\left(\mathrm{M} \mathrm{HRP} \cdot \mathrm{sec}\right.$ ) with $\mathrm{AR}$ and guaiacol in buffer solution), LOD of the $\mathrm{H}_{2} \mathrm{O}_{2}$ decomposition was about $6 \mathrm{pM} \mathrm{H}_{2} \mathrm{O}_{2} / \mathrm{sec}$ and $10 \mathrm{pM} \mathrm{H}_{2} \mathrm{O}_{2} / \mathrm{sec}$ in the case of $\mathrm{AR}$ and guaiacol, respectively.
\end{abstract}

\section{Introduction}

$\mathrm{H}_{2} \mathrm{O}_{2}$ is one of the reactive oxygen species (ROS) which should be considered in many chemical and biological processes, for example, in food chemistry and biology, physiological, pathological and pharmaceutical procedures, and environmental fields $[1,2]$. There is a large interest to reduce the formation of the ROS components because they may react with the components of the systems resulting in their degradation, consequently, reducing the efficiency of the reactions.

Due to the increasing role of free radical mechanisms in air and in aquatic environment, $\mathrm{H}_{2} \mathrm{O}_{2}$ has an increasing concentration (together with other reactive oxygen species) in the atmosphere and water [3]. In addition, it is a natural product of oxidative processes in metabolism of living cells (like electron transport of biological oxidation and photosynthesis) with a very wide apparent concentration range from few tens of pM to $\mathrm{mM}[4,5]$. Detection of extracellular $\mathrm{H}_{2} \mathrm{O}_{2}$ can be an important diagnostic tool for cancer cell lines expressing either transfected dual oxidase (DUOX) or endogenous DUOX (e.g., in thyroid, airway or colonic epithelium, and lung) (see [6], and the references in it).

Although $\mathrm{H}_{2} \mathrm{O}_{2}$ is a strong two-electron oxidant, many of its two-electron oxidation reactions are too slow to be biologically relevant due to the high activation energy of 
this process. There are, however, important exceptions. For example, metallocomplexes (e.g., metalloproteins) or specific proteins (thiol or methionine proteins) and lipids (especially unsaturated ones) are extremely sensitive to reactions with $\mathrm{H}_{2} \mathrm{O}_{2}[7,8]$.

Consequently, the rapid, accurate, sensitive, and selective determination of the spatial and temporal variations of these harmful reactive oxygen species is of great significance and became in the focus of many laboratories. It is not the aim of this publication to give a summary; however, it must be mentioned that numerous techniques have been used for the detection of $\mathrm{H}_{2} \mathrm{O}_{2}$ [9-12]. Besides the classical titrimetry [13], optical [14, 15], and infrared spectroscopy [16], electrochemical techniques coupled with the use of electrodes decorated by redox proteins are more and more promising ways to detect $\mathrm{H}_{2} \mathrm{O}_{2}$ [17-20]. Natural enzyme-like activity of enzyme mimetics (nanozymes) has been applied to detect various bio- and/or biologically relevant molecules and reviewed by Shin et al. [21]. There are many tasks that should be considered when different methods are used for specific applications. One should optimize the complication and cost of the method itself (the required instrumentation, like vibrational spectroscopies); the size of the device and the sample quantity; the response to be fast, reversible, and reproducible; the possibility of online, real-time detection; the sensitivity, selectivity and, cross-reactions or parallel reactions of the analytes.

The development of $\mathrm{H}_{2} \mathrm{O}_{2}$ sensors with low detection limit and wide responding range has become a rich research field these days. There are two main directions of strategies for the fabrication of sensitive and specific $\mathrm{H}_{2} \mathrm{O}_{2}$ detectors. One direction is a nonenzymatic platform which provides very rapid, high sensitivity detection of $\mathrm{H}_{2} \mathrm{O}_{2}$ and does not suffer from limitations which are inherently present in biological materials, like in enzyme proteins. These are usually related to the reduced stability when isolated from their natural (biological) environment due to high sensitivity to environmental factors and/or to autocatalytic degradation processes [22-25]. In addition, the nonenzymatic biosensors are usually simpler and of low cost, and thanks to recent developments their selectivity and sensitivity are increasing in recent publications $[24,26]$.

Another direction is the fabrication of enzyme protein activity based biosensors. Besides the difficulties in using biological materials (usually complicated and sometimes high cost immobilization procedures are required) it is a real challenge to use them in new generation technologies (like in optoelectronics, nanobionics, and biosensor technologies) because their function is extremely specific, sensitive, and selective. The definite advantage of enzymatic biosensors is that these are less sensitive to cross-reactions with electrochemical processes, which can modify the electrode surfaces and/or are reflected in kinetic limitations and overpotential. The most commonly used enzyme for the construction of electrochemical $\mathrm{H}_{2} \mathrm{O}_{2}$ biosensors is horseradish peroxidase (HRP), which catalyses the $\mathrm{H}_{2} \mathrm{O}_{2}$-dependent one-electron oxidation of suitable hydrogen donors efficiently [27, 28].

Thanks to the intensive research (see, e.g., crystallographic $[29,30]$ and spectroscopy [31-34] investigations and model calculations $[35,36])$ combined with site directed mutagenesis studies [37] we have quite solid knowledge about the molecular mechanism of catalytic processes of peroxidases with different reaction routes and substrates [38]. The structural, kinetic, and energetic details together with the known reaction stoichiometry allow using HRPs in promising applications in biosensor technology.

Transparent conducting metal oxide (TCO) electrodes are widely used in many fields of modern electronics (see [39], and the references in it) because these offer the combination of optical and electric methods in biosensor applications. The oxidized, coloured product of the enzyme reaction is usually very specific and its accumulation can be easily detected by optical spectroscopy, while the electric method offers good sensitivity $[40,41]$. The direct electron transfer between the HRP and the electrode is relatively slow and hardly detectable; however, in the presence of a suitable mediator (e.g., carbon nanotubes (CNTs)), it can be facilitated while the enzyme's bioactivity is largely retained [42].

Recently, we have fabricated an ITO/f-MCWNT ${ }^{\mathrm{COOH}}$ / HRP electrode, which was able to reduce $\mathrm{H}_{2} \mathrm{O}_{2}$, as proved by electrochemical (cyclic voltammetry) and optical (absorption change and fluorescence) measurements. The results showed that electron transfer can be facilitated between the active sites of the enzyme and the surface of the electrode and that the enzyme remains accessible for the substrate. The enzyme reaction was followed by measuring the fluorescence change of the coloured product of the guaiacol [43]. After optimizing the enzyme electrode preparation protocol and the fluorescence detection system the sensitivity of our measurement increased by several orders of magnitude which allowed monitoring the $\mathrm{H}_{2} \mathrm{O}_{2}$ concentration in real time. Introducing a sensitive $\mathrm{C}^{14}$ radioassay in determining the amount of bound enzyme the absolute enzyme activity was determined and compared to the one measured in solution. In addition, besides the guaiacol, another sensitive fluorescence probe, amplex red, was introduced and the enzyme activity and LOD of $\mathrm{H}_{2} \mathrm{O}_{2}$ detection are introduced.

\section{Materials and Methods}

2.1. Sample Preparation. The functional groups of carboxyl-functionalized multiwalled carbon nanotubes (fMCWNT $\left.{ }^{\mathrm{COOH}}\right)(0.14 \mathrm{mg} / \mathrm{mL})$ were activated by using crosslinkers N-hydroxysuccinimide (NHS, Sigma-Aldrich) and 1[3-dimethylaminopropyl]-3-ethyl-carbodiimide (EDC, Sigma-Aldrich). After the activation procedure, the mixture was dialysed in potassium phosphate buffer (PBS, $0.1 \mathrm{M}, \mathrm{pH} 7.0$ ) to remove the excess amount of the crosslinkers. Then the HRP enzyme solution ( $1 \mu \mathrm{M}$, salt free, Reanal) was added to the activated $\mathrm{f}-\mathrm{MCWNT}{ }^{\mathrm{COOH}}$ suspension and it was stirred intensively at $4^{\circ} \mathrm{C}$ for $2 \mathrm{~h}$. At the end, the sample was washed until the supernatant did not show enzyme activity and then separated by ultracentrifuge.

2.2. Absorption Kinetics and Enzyme Activity. Absorption change was measured at $470 \mathrm{~nm}$ (guaiacol, Sigma-Aldrich) and $570 \mathrm{~nm}$ (amplex red (AR), Sigma-Aldrich) by a singlebeam kinetic spectrophotometer of local design [44]. The 
good signal/noise ratio made it possible to measure even $10^{-4}-10^{-5}$ optical density change. By following the accumulation of the coloured products the amount and the rate of the $\mathrm{H}_{2} \mathrm{O}_{2}$ decomposition was calculated from the reaction stoichiometry. The enzyme reactions follow the reaction stoichiometry according to the following equations:

$$
\begin{aligned}
& 4 \mathrm{H}_{2} \mathrm{O}_{2}+4 \text { guaiacol } \stackrel{\text { enzyme }}{\longrightarrow} 8 \mathrm{H}_{2} \mathrm{O}+1 \text { tetraguaiacol } \\
& 1 \mathrm{H}_{2} \mathrm{O}_{2}+1 \text { amplex red } \stackrel{\text { enzyme }}{\longrightarrow} 1 \mathrm{H}_{2} \mathrm{O}+1 \text { resofurin. }
\end{aligned}
$$

The enzyme activity was determined from the absorption and fluorescence kinetics. By measuring the concentration change of the enzyme reaction's coloured product, the concentration change of $\mathrm{H}_{2} \mathrm{O}_{2}$ can be determined by the known molar extinction coefficients $\left(\varepsilon(\lambda)_{\text {tetraguaiacol }}=\right.$ $26611 \mathrm{M}^{-1} \mathrm{~cm}^{-1}$ and $\left.\varepsilon(\lambda)_{\text {resorufin }}=58000 \mathrm{M}^{-1} \mathrm{~cm}^{-1}\right)$. The absorption change was calculated by measuring the voltage of the detector after current/voltage conversion, which is proportional with the light intensity:

$$
\Delta E(t)=\log \frac{U_{0}}{U_{0}-\Delta U(t) / A} .
$$

Here $U_{0}$ is the DC level of the detector (typically $100 \mathrm{mV}$ ) and $\Delta U(t)$ is the voltage change in time accompanying the enzyme reaction and $A$ is the amplification. Applying the Beer-Lambert's law the amount of the reduced $\mathrm{H}_{2} \mathrm{O}_{2}$ can be calculated from the measured $E(t)$.

$$
\left[\mathrm{H}_{2} \mathrm{O}_{2}\right](t)=\frac{E(t)}{n \cdot \varepsilon(\lambda) \cdot l} .
$$

Here $l$ is the optical path and $n$ refers to the stoichiometric ratio of $\mathrm{H}_{2} \mathrm{O}_{2}$ and tetraguaiacol or resorufin, which was $4: 1$ or $1: 1$, respectively.

2.3. Fluorescence Measurements. Fluorescence was measured by a spectrofluorimeter (Perkin Elmer MPF44A) in a sensitive way with one hundred times amplification. The reaction was initiated by the addition of $\mathrm{H}_{2} \mathrm{O}_{2}$ to the mixture of the $\mathrm{f}-\mathrm{MCWNT} \mathrm{COOH}^{\mathrm{CHRP}}$ bionanocomposite and the guaiacol/amplex red hydrogen donors whose reagents can be simply oxidized and theirs oxidation results in coloured product (tetraguaiacol/resorufin). The excitation and the emission wavelengths were $300 \mathrm{~nm}$ and $355 \mathrm{~nm}$ or $545 \mathrm{~nm}$ and $585 \mathrm{~nm}$ in the case of guaiacol and amplex red, respectively.

On the one hand, measuring fluorescence change assures a more sensitive way of detection than measuring absorption change; on the other hand, the presence of carbon nanotubes makes the analysis more difficult because of the light scattering characteristics of the nanotubes.

The change in the fluorescence can be approximated by the following equation:

$$
I_{f}(t)=K^{\prime} \cdot I_{0} \cdot c(t) \cdot \varepsilon(\lambda) \cdot l \cdot Q .
$$

Here $I_{0}$ is the incident light intensity; $I_{f}(t)$ is the fluorescence intensity as a function of time; $c(t)$ is the concentration change of the coloured product as a function of time; $\varepsilon(\lambda)$ is the extinction coefficient; $l$ is the optical path; $Q$ is the quantum yield of fluorescence; and $K^{\prime}$ is the instrumental constant [43]. By knowing the amount of the enzyme, the enzyme activity can be determined in $\mathrm{M}_{\mathrm{H}_{2} \mathrm{O}_{2}} /\left(\mathrm{M}_{\text {enzyme }} \cdot \mathrm{s}\right)$ unit. Measurement of the fluorescence with high sensitivity allows us to determine the $\mathrm{H}_{2} \mathrm{O}_{2}$ concentration in real time without large incubation and integration time. The integration time for the measurement was typically one second.

2.4. Scanning Electron Microscopy. In order to visualize the surface coverage of ITO by the carbon nanotubes scanning electron microscopy (SEM) investigations were performed. SEM images were taken by a Hitachi S-4700 type II FE-SEM operating in the range of $3-5 \mathrm{kV}$. Prior to the measurement the samples were mounted on a conductive carbon tape.

2.5. Cyclic Voltammetry. The electrochemical activity of the enzyme electrode was checked by cyclic voltammetry as well. Cyclic voltammograms were measured using a PGSTAT10 potentiostat/galvanostat at ambient temperature. A threeelectrode cell containing $50 \mathrm{~mL}$ potassium phosphate buffer (0.1 M, pH 7.0) and $20 \mathrm{mM} \mathrm{KCl}$ was used. The cell was purged with high purity $\mathrm{N}_{2}$ prior to each measurement. The working electrode was the enzyme electrode fabricated from ITO, carboxyl-functionalized MWCNTs, and HRP. The counter and reference electrodes were platinum and $\mathrm{Ag} / \mathrm{AgCl}$, respectively. The scan rate was $50 \mathrm{mV} \mathrm{s}^{-1}$ [40].

2.6. Preparation of the ITO/f-MWCNT ${ }^{\mathrm{COOH}} / \mathrm{HRP}$ Enzyme Electrode. First the surface of ITO covered glass (CEC020B, Praezisions Glas \& Optik GmbH, Iserlohn, Germany) was cleaned by oxygen plasma cleaner and then silanized ((3aminopropyl) triethoxysilane) to create amino-functional groups on it. After silanization, the carboxyl groups of the functionalized MWCNTs $(0.14 \mathrm{mg} / \mathrm{mL})$ were activated by the addition of crosslinkers NHS $(0.15 \mathrm{mg} / \mathrm{mL})$ and EDC $(0.5 \mathrm{mg} / \mathrm{mL})$ solved in distilled water and deposited on the top of the ITO for $2 \mathrm{~h}$ and then washed intensively.

HRP was bound to the ITO/f-MCWNT ${ }^{\mathrm{COOH}}$ electrode by the same crosslinkers as used before by depositing the activated enzyme on the surface for $2 \mathrm{~h}$ at $4^{\circ} \mathrm{C}$. Then the electrode was washed intensively with phosphate buffer $(0.1 \mathrm{M}, \mathrm{pH} 7.0)$ and distilled water several times [45]. Schematic arrangement of the multilayer structure of the ITO/f-MCWNT ${ }^{\mathrm{COOH}} / \mathrm{HRP}$ electrode is presented by Figure 1 .

2.7. Measuring the Carbon Quantity. In order to determine the enzyme activity, the amount of the enzyme bound to the $\mathrm{f}-\mathrm{MCWNT}{ }^{\mathrm{COOH}}$ was determined. Since, the contribution of modern carbon (percent of modern carbon, pMC; [46]) should be different in MWCNTs and HRP, measuring the pMC of different samples offers sensitive detection of the sample quantity. The procedure was carried out shortly as follows.

The carbon content of the samples was liberated by sealed tube combustion method. The sample and the $\mathrm{MnO}_{2}$ oxidant were weighted into a glass tube. The tubes were evacuated to $<5 \cdot 10^{-3}$ mbar and sealed by a torch. The samples were 


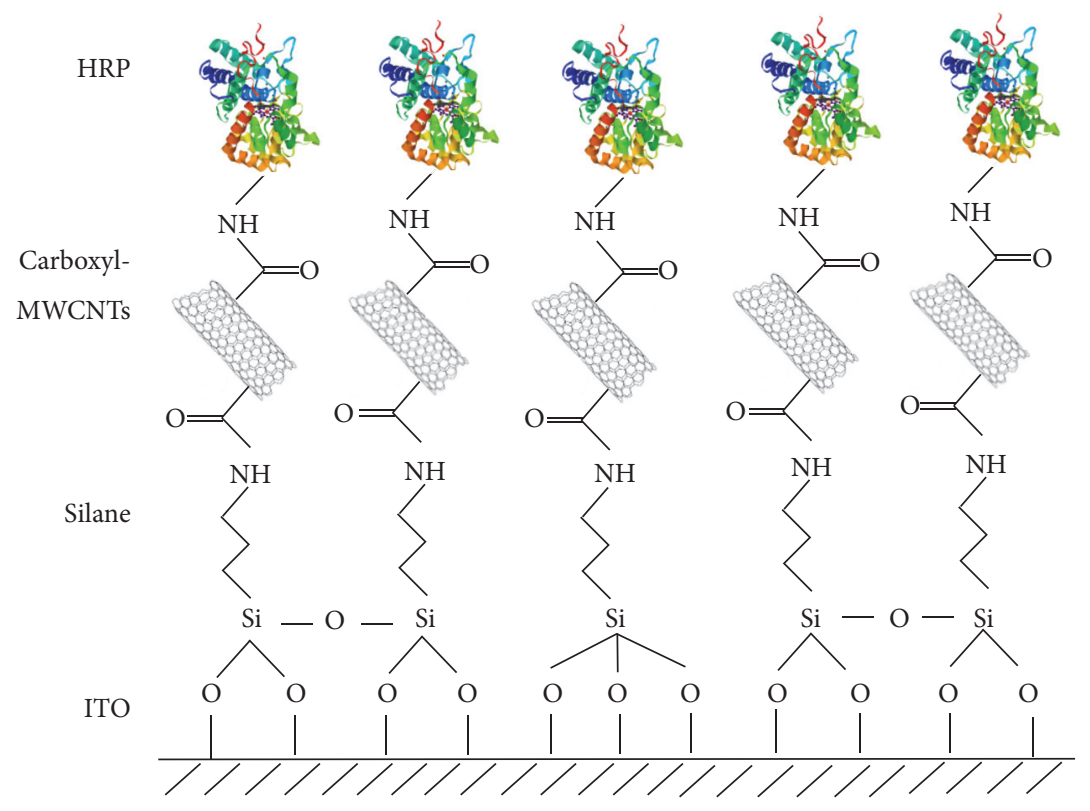

FIGURE 1: Schematic representation of the multilayer structure of the ITO/f-MCWNT ${ }^{\mathrm{COOH}} / \mathrm{HRP}$ electrode. The structure of the enzyme was downloaded from the Brookhaven Protein Data Bank (http://www.rcsb.org/) by using the 1H58.pdb data file and prepared by Jsmol program.

combusted to $\mathrm{CO}_{2}$ in a muffle furnace at $550^{\circ} \mathrm{C}$ for 24 hours. The gained $\mathrm{CO}_{2}$ was purified using a dedicated gas handling system equipped with cryogenic traps in order to remove the other combusted gas components [47]. The quantity of the pure $\mathrm{CO}_{2}$ was determined in a known volume by high-precision pressure sensor [48]. The yield of the carbon extraction can be calculated from the quantity of the pure $\mathrm{CO}_{2}$ gases. The trapped and cleaned $\mathrm{CO}_{2}$ gases have been converted to graphite by zinc reduction sealed tube graphitization method [49].

The measurements of the radiocarbon contents were carried out on a MICADAS (MIni CArbon DAting System [50, 51] type accelerator mass spectrometer in Institute for Nuclear Research, Debrecen, Hungary) [52]. In order to monitor and to take the possible modern carbon contamination during the pretreatment and combustion process into account, we have extracted chemical standards with well-known radiocarbon activity (IAEA C7 and C8, [53]) on the same treatment line and measured them together with the samples in the same magazines. The pMC (5) unit was used to compare the radiocarbon contents of the samples. All of the radiocarbon results were processed using the BATS AMS data evaluation software developed by Wacker et al., ETH Zurich [54].

\section{Results and Discussions}

3.1. Preparation of the Enzyme Electrode. Figure 2 shows the SEM image of $\mathrm{f}-\mathrm{MCWNT}{ }^{\mathrm{COOH}}$ bound to the surface of ITO which serves as a base for the immobilization of the HRP enzyme. The image indicates that the coverage is not homogenous, but dense enough with f-MCWNT ${ }^{\mathrm{COOH}}$ for the further steps of the preparation. Conducting mechanisms of the transparent conducting oxides (TCOs) also of the ITO depend strongly on the grain and layer structure,

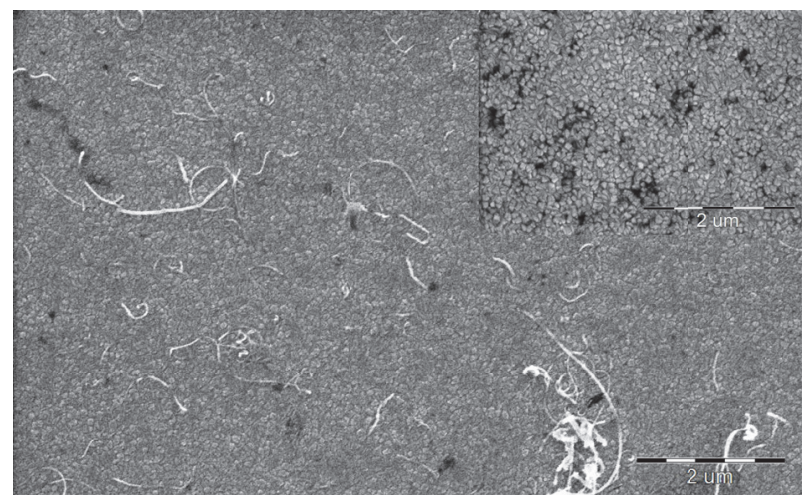

FIGURE 2: Scanning electron microscopy image of carboxylfunctionalized MWCNT attached to the surface of ITO. Insert shows the SEM image of the bare ITO, for comparison.

consequently, on the deposition technique, on the quality, and on prehistory of the oxide film [55-58]. The SEM image of the bare ITO shows that the surface morphology (i.e., the homogenous surface coverage and the organization of the rain structure) of the ITO in the biohybrid sample is essentially the same as before the treatment (cf. with insert of Figure 2).

3.2. Enzyme Activity in Solution. Our aim was to design an ITO/f-MCWNT ${ }^{\mathrm{COOH}} / \mathrm{HRP}$ electrode in order to determine the concentration of $\mathrm{H}_{2} \mathrm{O}_{2}$ in real time in a sensitive way. Measuring fluorescence instead of light absorption of the product of the enzyme reaction is more advantageous in this system because of two reasons. On the one hand, fluorescence measurement is more sensitive and, on the other hand, because of the light scattering of the $\mathrm{f}-\mathrm{MCWNT} \mathrm{COOH}^{\mathrm{CHRP}}$ 


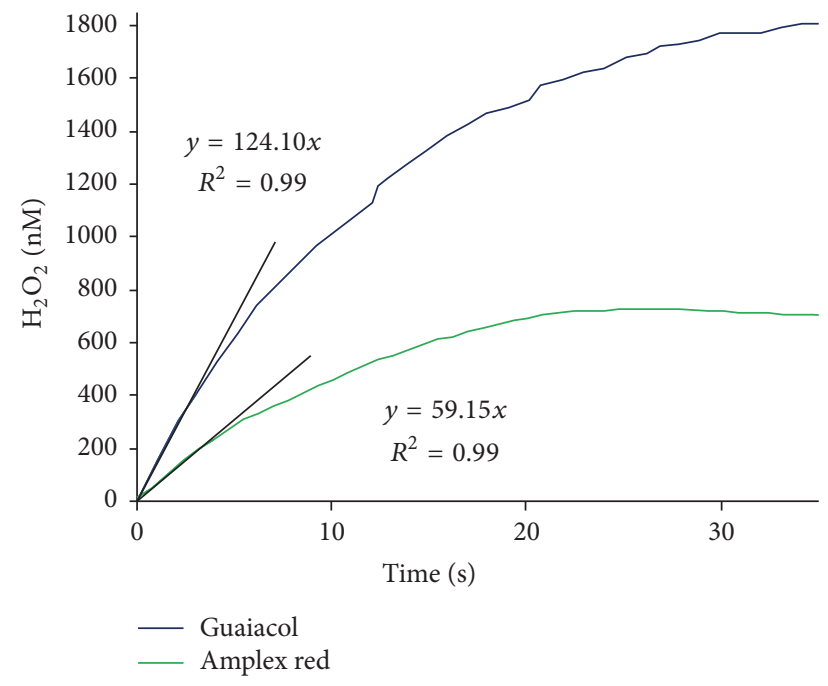

FIgURE 3: The amount of $\mathrm{H}_{2} \mathrm{O}_{2}$ reduced by $20 \mathrm{nMHRP}$ (with guaiacol and amplex red as indicated) as a function of time. Figure was made by the absorption change of guaiacol and AR in PBS buffer solution $(0.1 \mathrm{M}, \mathrm{pH} 7.0)$. Figure shows the initial slopes and theirs straight-line equations with the goodness-of-fits $\left(R^{2}\right)$.

complex Beer-Lambert's law of absorption cannot be applied directly.

First, the kinetics of the absorption change of tetraguaia$\mathrm{col}$ and resorufin due to the enzyme reaction (see Materials and Methods) was measured and the rate of the $\mathrm{H}_{2} \mathrm{O}_{2}$ decomposition was calculated at different enzyme concentrations without MWCNT in PBS buffer solution; then the initial rate of the decomposition was determined in each case. Figure 3 shows results of typical measurements at the concentration of $20 \mathrm{nM} \mathrm{HRP}$ after the addition of guaiacol $(3.5 \mathrm{mM})$ and amplex red $(6.5 \mu \mathrm{M})$, as indicated.

In the set of second experiment the conversion of guaiacol to tetraguaiacol and amplex red to resorufin was followed by measuring the fluorescence change with different enzyme concentrations (same as used for measuring the absorption change) and the initial rate of the fluorescence change was calculated (Figure 4). These instrumental conditions were used for determining the enzyme activity of the $\mathrm{f}-\mathrm{MCWNT}^{\mathrm{COOH}}$ / HRP complex.

The initial slopes of the fluorescence changes were calibrated to the initial rates of the absorption measurements for $\mathrm{H}_{2} \mathrm{O}_{2}$ decomposition (Figure 5). This way, by using the same instrumental conditions, the rate of the $\mathrm{H}_{2} \mathrm{O}_{2}$ decomposition can be determined from the fluorescence change measurements belonging to certain complexes and electrodes containing the HRP enzyme.

Using the initial slope of the fluorescence change the rate of the decomposition of $\mathrm{H}_{2} \mathrm{O}_{2}$, consequently, the enzyme activity of $5 \mathrm{M} \mathrm{H}_{2} \mathrm{O}_{2} /(\mathrm{M} \mathrm{HRP} \cdot \mathrm{sec})\left(R^{2}=0.99\right)$ and $2 \mathrm{M} \mathrm{H}_{2} \mathrm{O}_{2} /(\mathrm{M} \mathrm{HRP} \cdot \mathrm{sec})\left(R^{2}=0.99\right)$ was determined and used for further calibrations of the fluorescence measurement in case of guaiacol and $\mathrm{AR}$, respectively. By using the calibrations the limit of detection of $\mathrm{H}_{2} \mathrm{O}_{2}$ by the HRP itself was calculated in both cases and it was found to be

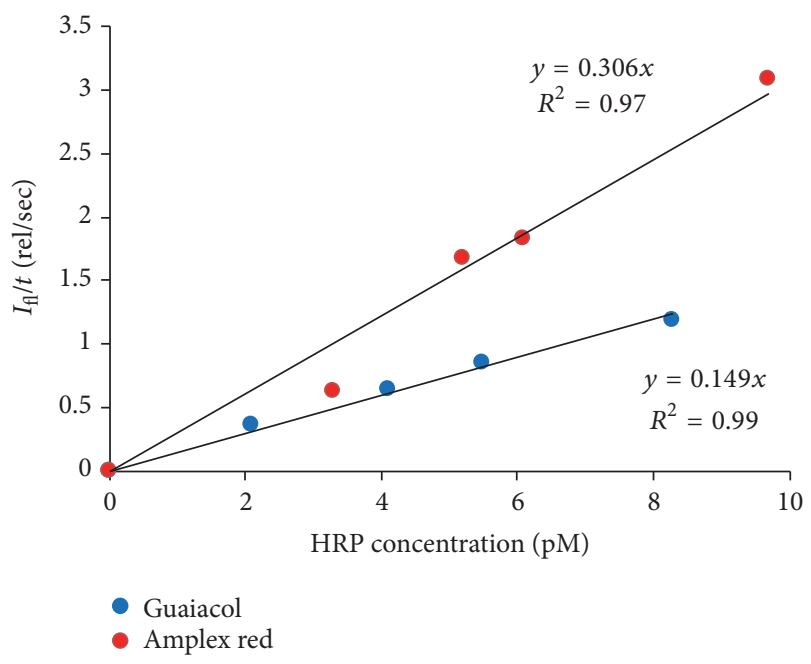

FIGURE 4: The initial rate of the fluorescence change as a function of the enzyme concentration. Figure was made by the fluorescence change of guaiacol $(3.5 \mathrm{mM})$ and $\mathrm{AR}(6.5 \mu \mathrm{M})$ in PBS buffer solution $(0.1 \mathrm{M}, \mathrm{pH} 7.0)$. Figure shows the straight-line equations with the goodness-of-fits $\left(R^{2}\right)$.

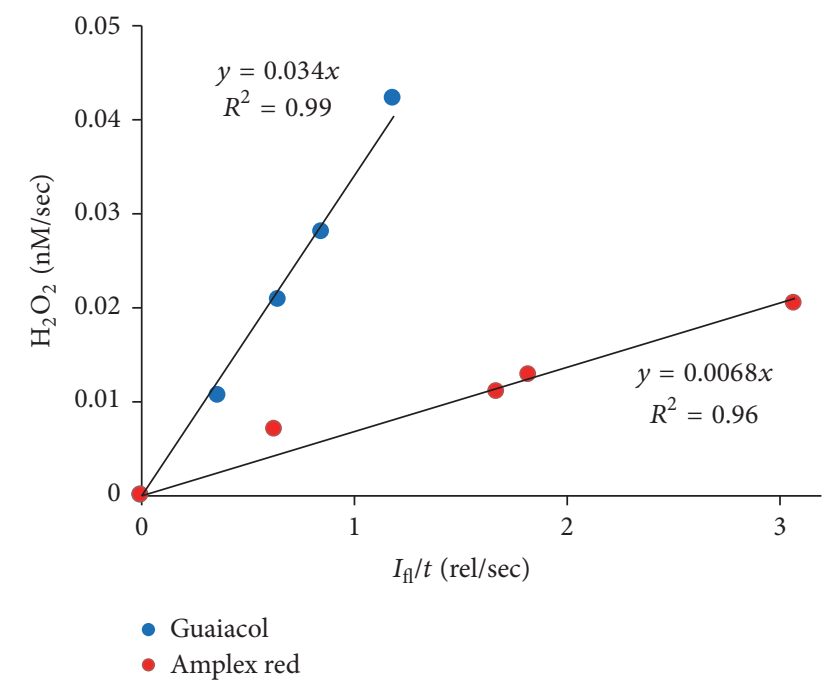

FIGURE 5: The initial rate of the $\mathrm{H}_{2} \mathrm{O}_{2}$ decomposition as a function of the initial slope of the fluorescence change of tetraguaiacol and resorufin. Figure shows the straight-line equations with the goodness-of-fits $\left(R^{2}\right)$.

$124 \mathrm{nM} \mathrm{H}_{2} \mathrm{O}_{2} \mathrm{~s}^{-1}$ in case of guaiacol and $59 \mathrm{nM} \mathrm{H}_{2} \mathrm{O}_{2} \mathrm{~s}^{-1}$ in case of $\mathrm{AR}$, in good agreement with the values published earlier [43].

3.3. Enzyme Activity of the $f-M W C N T^{\mathrm{COOH}} / \mathrm{HRP}$ Complex. As an introductory experiment it should be proved that (a) the HRP binds to the CNT, (b) the active centre of the enzyme remains accessible to the substrates (i.e., the protein keeps the enzyme activity), and (c) there are no substantial changes in the protein conformation after the binding which affect the enzyme reaction. For this reason we have bound HRP to carboxyl- and amine-functionalized MWCNT in suspension 


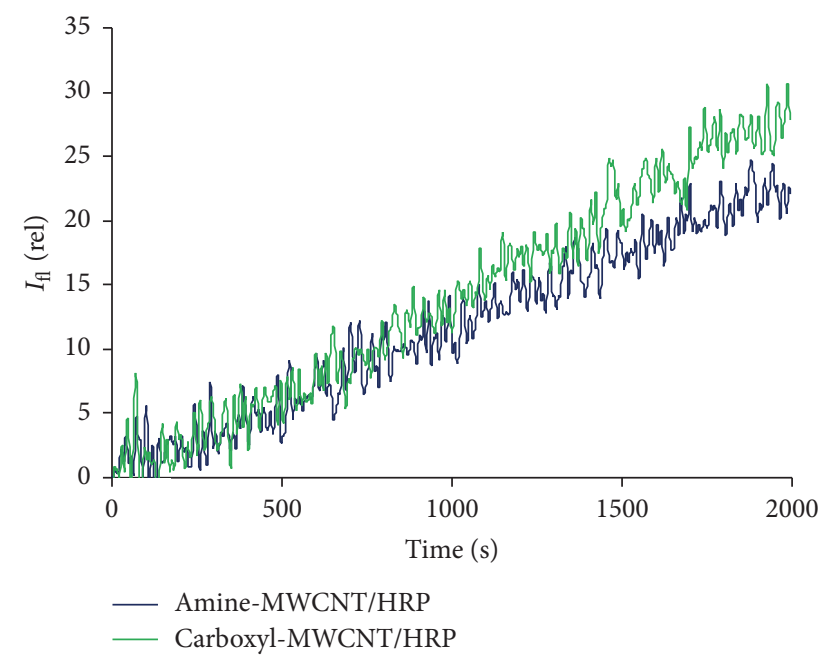

FIGURE 6: The fluorescence change of the tetraguaiacol produced by the enzyme reaction of HRP bound to the $\mathrm{f}-\mathrm{MWCNT}^{\mathrm{NH} 2}$ /and f-MCWNT ${ }^{\mathrm{COOH}}$ as a function of time.

and the enzyme reaction was followed by fluorescence measurements using guaiacol as $\mathrm{e}^{-}$-donor substrate.

3.3.1. Rate of $\mathrm{H}_{2} \mathrm{O}_{2}$ Decomposition by the f-MWCNT ${ }^{\mathrm{COOH}}$ / HRP Complex. Figure 6 shows that HRP bound either to amine- or to carboxyl-functionalized MWCNTs showed enzyme activity. The smaller yield of the amine-functionalized sample can probably be explained by the smaller amount of enzyme bound to the MWCNT. This can be due to the glutaraldehyde (GTA) crosslinker, which crosslinks the amine groups. In order to avoid this inherent crosslinkings of the MWCNTs in the sample we used carboxyl-functionalized MWCNTs for further experiments.

Figure 7 shows the emission spectra of the tetraguaiacol produced by the $\mathrm{f}-\mathrm{MCWNT} \mathrm{COOH}^{\mathrm{CHRP}}$ complex added at different concentrations, at the rate of the enzyme reaction's saturation (after fifteen minutes of starting the reaction, when the reaction rate is maximal). The excitation wavelength was $300 \mathrm{~nm}$. The increase of the fluorescence clearly indicates that the $\mathrm{f}-\mathrm{MCWNT} \mathrm{COOH}^{\mathrm{CHRP}}$ complex possesses considerable enzyme activity; that is, the HRP was bound to f$\mathrm{MCWNT}^{\mathrm{COOH}} \mathrm{s}$ and the active centre remained accessible to the substrates after the binding. f-MCWNT ${ }^{\mathrm{COOH}}$ suspension alone did not show fluorescence increase indicating that the illumination of the carbon nanotube without the enzyme does not contribute to the guaiacol oxidation. The f$\mathrm{MCWNT}^{\mathrm{COOH}} / \mathrm{HRP}$ complex in the presence of guaiacoland in the absence of $\mathrm{H}_{2} \mathrm{O}_{2}$-also did not show change in the fluorescence indicating that HRP alone does not oxidize the guaiacol.

After measuring the fluorescence change accompanying the enzyme reaction of the guaiacol or amplex red added to the $\mathrm{f}-\mathrm{MCWNT} \mathrm{COOH}^{\mathrm{CHRP}}$ complex, the initial rate of the enzyme reaction was determined (Figure 8). Under our experimental conditions, based on the calibrations (see Section 3.2), our complex was able to reduce $\mathrm{H}_{2} \mathrm{O}_{2}$ with the

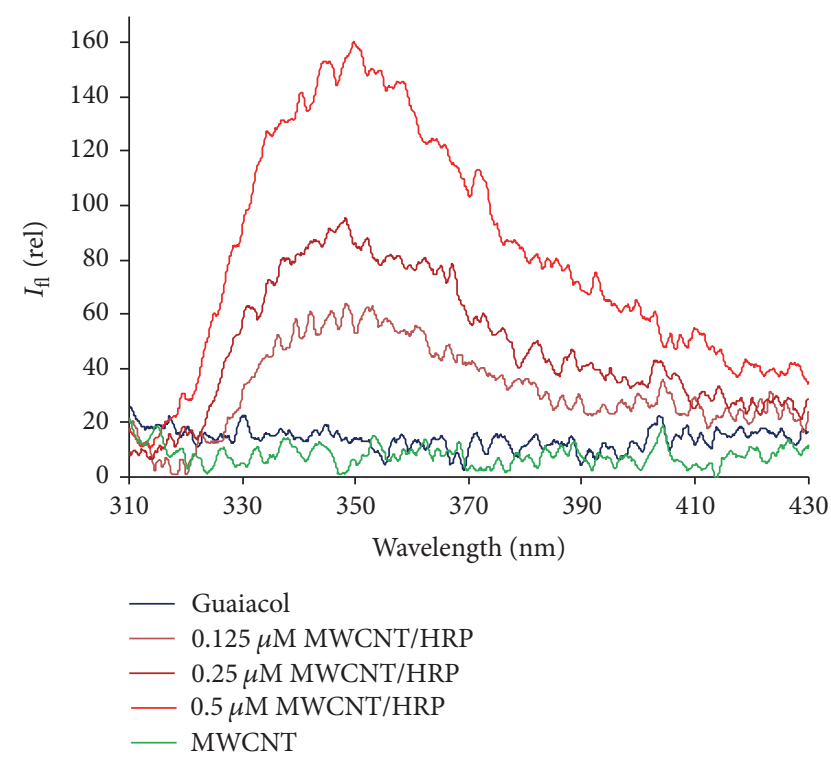

FIGURE 7: The emission spectra of tetraguaiacol produced by the enzyme reaction of $\mathrm{f}-\mathrm{MCWNT}{ }^{\mathrm{COOH}} / \mathrm{HRP}$ complex before (guaiacol) and after the reaction at different HRP incubation concentrations (as indicated) and the carboxyl-functionalized MWCNT as a reference. Measurement was done as described in Materials and Methods.

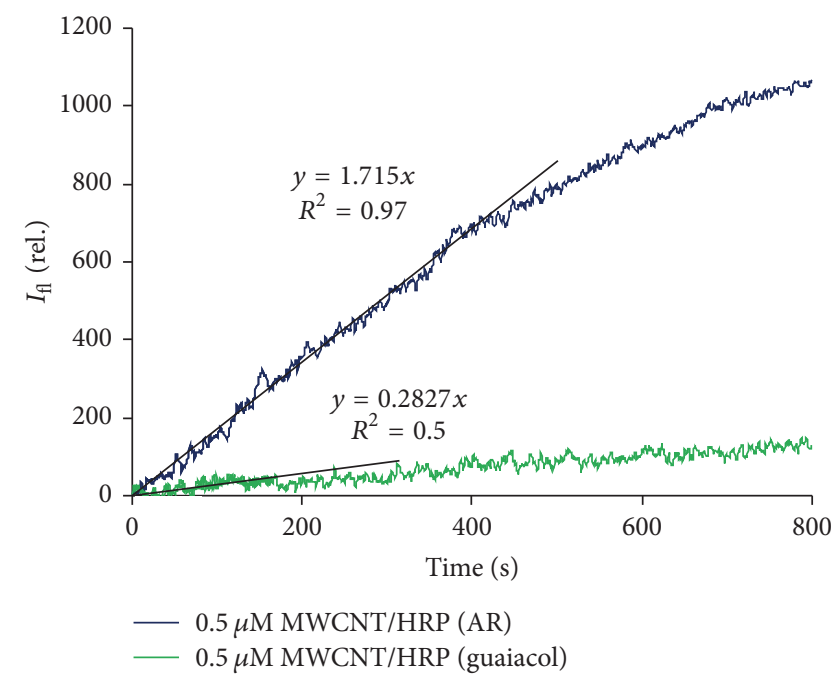

FIGURE 8: The fluorescence change of the coloured products of guaiacol and amplex red substrates oxidized by $0.5 \mu \mathrm{M} \mathrm{f}$ $\mathrm{MCWNT}^{\mathrm{COOH}} / \mathrm{HRP}$ complex as a function of time. Figure also shows the best fits of the initial changes of the signals and their equations. $R^{2}$, the goodness-of-fit, is also indicated.

rate of $9.6 \mathrm{pM} \mathrm{H}_{2} \mathrm{O}_{2} \mathrm{~s}^{-1}$ and $12 \mathrm{pM} \mathrm{H}_{2} \mathrm{O}_{2} \mathrm{~s}^{-1}$ in the case of guaiacol and $\mathrm{AR}$, respectively. These resolutions were better than the ones measured in solution by about 6-4 orders of magnitudes (cf. Section 3.2).

3.3.2. Enzyme Activity of the $-\mathrm{MWCNT}^{\mathrm{COOH}} / \mathrm{HRP}$ Complex. In order to determine the enzyme activity of the $\mathrm{f}$ $\mathrm{MCWNT}^{\mathrm{COOH}} / \mathrm{HRP}$ complex the amount of the protein 
bound to the MWCNT was determined. For this reason the pMC (5) unit was determined for the HRP, f-MCWNT ${ }^{\mathrm{COOH}}$, and $\mathrm{f}-\mathrm{MCWNT} \mathrm{COOH}^{\mathrm{CHRP}}$ samples.

The percent of modern carbon is defined as

$$
\mathrm{pMC}=\frac{A_{\mathrm{SN}}}{A_{\mathrm{ON}}} \cdot 100 \%,
$$

where $A_{\mathrm{SN}}$ is the specific activity of the sample normalized for fractionation and $A_{\mathrm{ON}}$ is the specific activity of NIST-SRM4990c oxalic acid standard normalized for fractionation.

The HRP fraction of the $\mathrm{f}-\mathrm{MCWNT} \mathrm{COOH}^{\mathrm{CHRP}}$ complex is obtained by ${ }^{14} \mathrm{C}$ balance equation. Radiocarbon content of the two-component mixture is defined as

$$
\begin{aligned}
\mathrm{pMC}_{\mathrm{f}-\mathrm{MWCNT}^{\mathrm{COOH}} / \mathrm{HRP}}= & F_{\mathrm{HRP}} \cdot \mathrm{pMC}_{\mathrm{HRP}}+\left(1-F_{\mathrm{HRP}}\right) \\
& \cdot \mathrm{pMC}_{\mathrm{f}-\mathrm{MWCNT}^{\mathrm{COOH}},}
\end{aligned}
$$

where $\mathrm{pMC}_{\mathrm{HRP}}, \mathrm{pMC}_{\mathrm{f}-\mathrm{MCWNT}}{ }_{\mathrm{COOH}}$, and $\mathrm{pMC}_{\mathrm{f}-\mathrm{MCWNT}}{ }^{\mathrm{COOH}} / \mathrm{HRP}$ are the measured radiocarbon content of the HRP, $\mathrm{f}$ $\mathrm{MCWNT}^{\mathrm{COOH}}$, and $\mathrm{f}-\mathrm{MCWNT}{ }^{\mathrm{COOH}} / \mathrm{HRP}$ complex, respectively. $F_{\mathrm{HRP}}$ is the HRP fraction of the radiocarbon content of the $\mathrm{f}-\mathrm{MCWNT} \mathrm{COOH}^{\mathrm{CHRP}}$ complex. The HRP fraction of the mixture is obtained after the rearrangement of (6):

$$
\begin{aligned}
& F_{\mathrm{HRP}}=\frac{\mathrm{pMC}_{\mathrm{f}-\mathrm{MWCNT} \mathrm{T}^{\mathrm{COOH}} / \mathrm{HRP}}-\mathrm{pMC}_{\mathrm{f}-\mathrm{MWCNT} \mathrm{T}^{\mathrm{COOH}}}}{\mathrm{pMC}_{\mathrm{HRP}}-\mathrm{pMC}_{\mathrm{f}-\mathrm{MWCNT}^{\mathrm{COOH}}}} \\
& \text {. 100\%. }
\end{aligned}
$$

Finally, the total HRP/f-MCWNT ${ }^{\mathrm{COOH}}$ ratio and the amount of HRP by the known molecular weight (MW: $44 \mathrm{kDa}, 45 \%$ carbon content) can be calculated using the HRP fraction constant and the carbon extraction yields of the appropriate components. The data obtained during the determination of radiocarbon quantity are summarized in Table 1.

By using the (5)-(7) under oversaturating enzyme concentration during the preparation procedure the $\mathrm{w} / \mathrm{w}$ ratio of the HRP/f-MWNT ${ }^{\mathrm{COOH}}$ is 2.7. Using the rates of $\mathrm{H}_{2} \mathrm{O}_{2}$ decompositions (cf. Figures 5 and 8 ) the enzyme activity of 1.3 $10^{-2} \mathrm{M} \mathrm{H}_{2} \mathrm{O}_{2} /$ (M HRP.sec) and $1.010^{-2} \mathrm{M} \mathrm{H}_{2} \mathrm{O}_{2}$ /(HRP.sec) was calculated for $\mathrm{AR}$ and guaiacol, respectively. It is interesting to note that these values after the binding in the composite complex are about two orders of magnitudes smaller than the ones found in solution (cf. Section 3.2); however, the LOD is reduced to the concentration of pM. This probably is due to the fact that the reduced accessibility/functionality of the active centre is compensated by the larger local concentration of the enzyme after the binding. The reduced catalytic activity of the enzymes after the binding to CNTs is known in the literature and is already demonstrated by other groups as well [59-61]. However, we do not have experimental evidence until now for the larger sensitivity for LOD. If it is related to the larger local concentration of the enzyme after the binding it should be sensitive to the concentration of the reactants, which requires systematic sets of experiments. The investigation of this possibility is under progress in our laboratory.

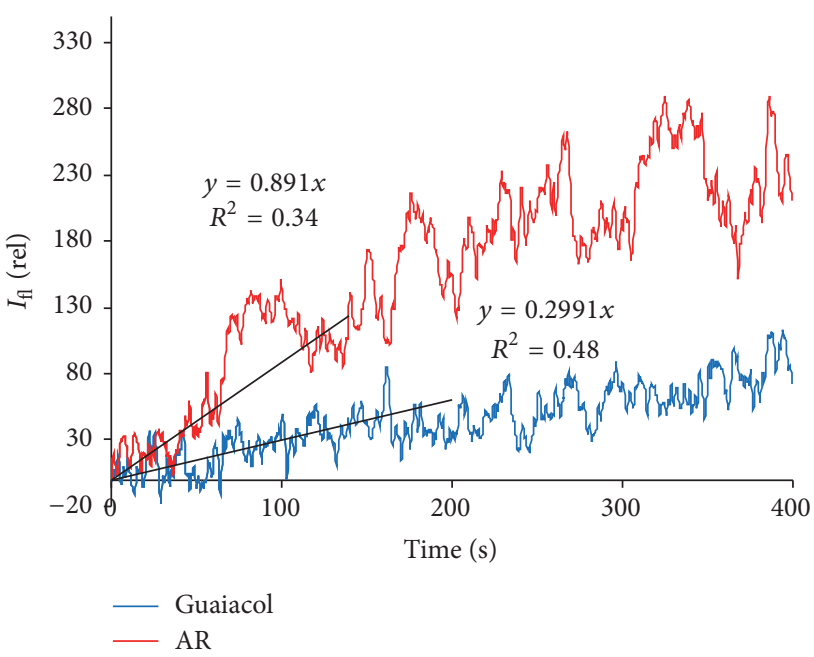

Figure 9: The fluorescence change of the coloured products of guaiacol and amplex red substrates oxidized by the ITO/f$\mathrm{MCWNT}^{\mathrm{COOH}} / \mathrm{HRP}$ electrode as a function of time. Figure also shows the best fits of the initial changes of the signals and their equations. $R^{2}$, the goodness-of-fit, is also indicated.

3.4. Rate of $\mathrm{H}_{2} \mathrm{O}_{2}$ Decomposition by the ITO/f-MWCNT ${ }^{\mathrm{COOH}}$ / HRP Electrode. First, the fluorescence of the substrates oxidized by the HRP was measured in the well-known system (Figure 9). The ITO/f-MCWNT ${ }^{\mathrm{COOH}} / \mathrm{HRP}$ electrode was placed in a $1 \mathrm{~cm}$ cuvette containing the guaiacol (or AR) in PBS buffer solution (0.1 M; pH 7.0); then the $\mathrm{H}_{2} \mathrm{O}_{2}$ was added to initiate the enzyme reaction. Based on the calibrations, the rate of the $\mathrm{H}_{2} \mathrm{O}_{2}$ decomposition can be calculated from the slope of the fluorescence change of our samples. The initial rate of the $\mathrm{H}_{2} \mathrm{O}_{2}$ decomposition was found to be $10 \mathrm{pM} \mathrm{H}_{2} \mathrm{O}_{2} / \mathrm{sec}$ and $6 \mathrm{pM} \mathrm{H}_{2} \mathrm{O}_{2} / \mathrm{sec}$ for guaiacol and $\mathrm{AR}$, respectively.

3.5. Cyclic Voltammetry. Our principal aim is to design a device which can be a base for the detection of $\mathrm{H}_{2} \mathrm{O}_{2}$ in a sensitive way. One classical way is the detection of luminescence (fluorescence) of the coloured product of the enzyme reaction; however, the sensitive detection usually requires sophisticated instrumentation (photomultiplier, high voltage power supply, amplifiers, etc). However, measuring the electric signal accompanying the redox transitions of the enzyme reactions offers large sensitivity and relatively simple instrumentation. It should be noted that the interpretation of the data is sometimes difficult and requires careful considerations. It can be a successful strategy to combine measurements of the optical and electric signals accompanying the enzyme reaction parallel.

In order to do this we have bound the f-MCWNT ${ }^{\mathrm{COOH}}$ / HRP complex to ITO which can be applied as a working electrode in a classical electrochemical cell. After the construction of this special enzyme electrode the cyclic voltammograms were recorded in the absence and in the presence of the $\mathrm{H}_{2} \mathrm{O}_{2}$ substrate. Figure 10 shows that there is a catalytic transition at around $-350 \mathrm{mV}$ [62] when the enzyme electrode is used in the electrochemical cell in the presence 
TABLE 1: Summary of data obtained during determination of the radiocarbon quantity.

\begin{tabular}{|c|c|c|c|c|}
\hline Sample & Sample quantity (mg) & Measured carbon (mg) & Yield (\%) & $\mathrm{pMC}$ \\
\hline HRP & 3.0 & 1.3 & 43.1 & $145.2 \pm 0.4$ \\
\hline$f-M W C N T^{C O O H}$ & 1.1 & 1.0 & 88.6 & $46.5 \pm 8.3$ \\
\hline$f-M W C N T^{\mathrm{COOH}} / \mathrm{HRP}$ & 3.2 & 0.5 & 16.4 & $100.1 \pm 0.5$ \\
\hline $\mathrm{F}_{\mathrm{HRP}}$ & & $54.0 \pm 2.0$ & & \\
\hline
\end{tabular}

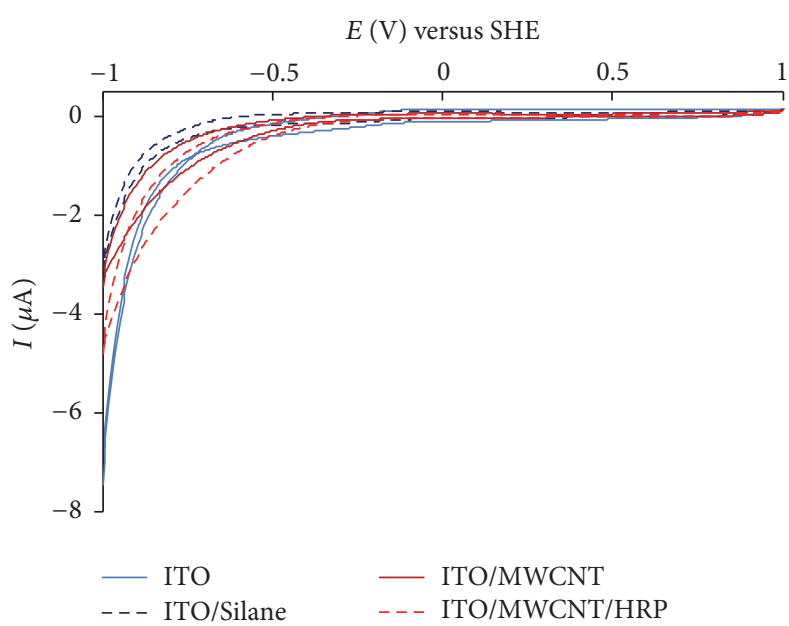

(a)

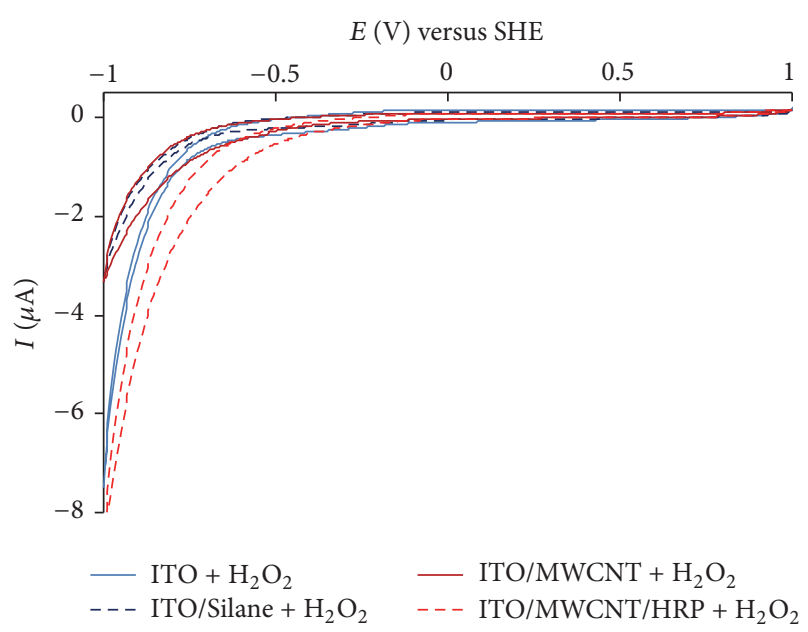

(b)

FIGURE 10: Cyclic voltammograms of ITO, silanized ITO (ITO/silane), ITO/f-MCWNT ${ }^{\mathrm{COOH}}$ (as references), and the enzyme electrode fabricated with HRP immobilized on $\mathrm{f}-\mathrm{MCWNT}^{\mathrm{COOH}}$ deposited on ITO (ITO/MWCNT/HRP), before (a) and after the addition $5 \mathrm{mM} \mathrm{H}_{2} \mathrm{O}_{2}$ (b).

of $\mathrm{H}_{2} \mathrm{O}_{2}$, indicating that the electrode is capable of catalysing the decomposition of $\mathrm{H}_{2} \mathrm{O}_{2}$. Neither the bare ITO electrode nor the silanized ITO or the $\mathrm{f}-\mathrm{MCWNT} \mathrm{COOH}^{\mathrm{Cl}}$ alone facilitates electrochemical transition at this potential in the presence of $\mathrm{H}_{2} \mathrm{O}_{2}$ [43].

3.6. Reliability, Reproducibility, and Specificity. When new biohybrid material is designed for a successful application (e.g., using them for biosensors) special attention should be paid to the reliability and reproducibility of the measurement and the specificity and stability of the device. The reliability and reproducibility in our case are highly dependent on the successful enzyme binding procedure, which can be monitored essentially by SEM. The sample which did not show sufficient coverage (by visual observation) was not used for further experiment. However, after finding the most appropriate preparation procedure (physico-/chemical parameters and incubation times) the reliability and sensitivity of the measurements increased significantly.

The investigation of specificity is a difficult, however, important issue and should be a topic for further measurements. There can be alternative substrates for HRP (like ascorbate, SH-substrates, etc.) or other enzymes (like catalases) which can be in competition with HRP, specially, under real tissue conditions. The possibilities for cross-reactions, for over- or underestimation of determination of $\mathrm{H}_{2} \mathrm{O}_{2}$ and advantages or disadvantages of using HRP electrodes are summarized by Maghzal et al. and Grisham [63, 64]. These investigations are under progress in our laboratory.

\section{Summary}

Our aim was to create a system suitable for detecting $\mathrm{H}_{2} \mathrm{O}_{2}$ in a sensitive way. We applied two kinds of substrates (guaiacol and amplex red), whose reagents can be oxidized in a multistep cation radical mechanism and theirs oxidation results in coloured products (tetraguaiacol and resorufin). The accumulation of these products can then be easily detected by specific light absorption or emission (fluorescence) spectroscopy. By determining the concentration of the products, the concentration change of the hydrogen peroxide can be calculated in absolute value. By using the calibration made from the absorption kinetic and fluorescence measurements belonging to the same enzyme concentrations, we determined the enzyme activity of horseradish peroxidase, which were $5 \mathrm{M} \mathrm{H}_{2} \mathrm{O}_{2} /$ ( $\mathrm{M} \mathrm{HRP}$.sec) and $2 \mathrm{M} \mathrm{H}_{2} \mathrm{O}_{2} /$ (M HRP $\cdot \mathrm{sec})$ for guaiacol and amplex red, respectively, and the limit of detection of $\mathrm{H}_{2} \mathrm{O}_{2}$, which was $124 \mathrm{nM} \mathrm{H}_{2} \mathrm{O}_{2} \mathrm{~s}^{-1}$ and $59 \mathrm{nM} \mathrm{H}_{2} \mathrm{O}_{2} \mathrm{~s}^{-1}$ for guaiacol and amplex red, respectively. We bound the enzyme to carboxyl-functionalized carbon nanotubes, and then an electrode was prepared by immobilizing the complex on the surface of the silanized ITO. Although the enzyme activity was smaller by about two orders of magnitude when the enzyme was bound 
to the f-MWCNTs $\left(1.310^{-2} \mathrm{M} \mathrm{H}_{2} \mathrm{O}_{2}\right.$ /(M HRP.sec) and $1.010^{-2} \mathrm{M} \mathrm{H}_{2} \mathrm{O}_{2} /(\mathrm{MHRP} \cdot \mathrm{sec})$ for $\mathrm{AR}$ and guaiacol, resp.) the LOD of the $\mathrm{H}_{2} \mathrm{O}_{2}$ decomposition was in the range of picomole. Morphological characterization (SEM) of the electrode showed that the binding was successful and it was able to reduce $\mathrm{H}_{2} \mathrm{O}_{2}$ as proved by electrochemical (cyclic voltammetry) measurements. By using the calibration made from the absorption kinetic and fluorescence measurements we determined the limit of detection of $\mathrm{H}_{2} \mathrm{O}_{2}$ of the complex and the electrode: $\mathrm{f}-\mathrm{MCWNT} \mathrm{COOH}^{\mathrm{CHRP}}$ with guaiacol $9.6 \mathrm{pM} \mathrm{H}_{2} \mathrm{O}_{2} \mathrm{~s}^{-1}$; with amplex red $12 \mathrm{pM} \mathrm{H}_{2} \mathrm{O}_{2} \mathrm{~s}^{-1}$; ITO/f$\mathrm{MCWNT}^{\mathrm{COOH}} / \mathrm{HRP}$ with guaiacol $10 \mathrm{pM} \mathrm{H}_{2} \mathrm{O}_{2} \mathrm{~s}^{-1}$; with amplex red $6 \mathrm{pM} \mathrm{H}_{2} \mathrm{O}_{2} \mathrm{~s}^{-1}$.

\section{Competing Interests}

The authors declare that there is no conflict of interests regarding the publication of this paper.

\section{Acknowledgments}

This work was supported by the grants from the Hungarian Scientific Research Fund OTKA K112688, PD116739, and PD121225, from Switzerland through the Swiss Contribution (SH/7/2/20), and from GINOP-2.3.2-15-2016-00009. Tibor Szabó acknowledges the support by the ÚNKP 16-3 New National Excellence Program of the Ministry of Human Capacities in Hungary. Thanks are due to Ms. Judit Tóth for the valuable technical assistance.

\section{References}

[1] A. Salimi, R. Hallaj, S. Soltanian, and H. Mamkhezri, "Nanomolar detection of hydrogen peroxide on glassy carbon electrode modified with electrodeposited cobalt oxide nanoparticles," Analytica Chimica Acta, vol. 594, no. 1, pp. 24-31, 2007.

[2] Y. Sang, L. Zhang, Y. F. Li, L. Q. Chen, J. L. Xu, and C. Z. Huang, "A visual detection of hydrogen peroxide on the basis of Fenton reaction with gold nanoparticles," Analytica Chimica Acta, vol. 659, no. 1-2, pp. 224-228, 2010.

[3] J. Mao, D. J. Jacob, M. J. Evans et al., "Chemistry of hydrogen oxide radicals $\left(\mathrm{HO}_{x}\right)$ in the Arctic troposphere in spring," Atmospheric Chemistry and Physics, vol. 10, no. 13, pp. 58235838, 2010.

[4] Q. Jöbsis, H. C. Raatgeep, P. W. M. Hermans, and J. C. de Jongste, "Hydrogen peroxide in exhaled air is increased in stable asthmatic children," European Respiratory Journal, vol. 10, no. 3, pp. 519-521, 1997.

[5] B. A. Wagner, C. B. Evig, K. J. Reszka, G. R. Buettner, and C. P. Burns, "Doxorubicin increases intracellular hydrogen peroxide in PC3 prostate cancer cells," Archives of Biochemistry and Biophysics, vol. 440, no. 2, pp. 181-190, 2005.

[6] W. M. Nauseef, "Detection of superoxide anion and hydrogen peroxide production by cellular NADPH oxidases," Biochimica et Biophysica Acta-General Subjects, vol. 1840, no. 2, pp. 757767, 2014.

[7] C. C. Winterbourn, "The biological chemistry of hydrogen peroxide," Methods Enzymology, vol. 528, pp. 3-25, 2013.

[8] C. C. Winterbourn, “The challenges of using fluorescent probes to detect and quantify specific reactive oxygen species in living cells," Biochimica et Biophysica Acta-General Subjects, vol. 1840, no. 2, pp. 730-738, 2014.

[9] S. Chen, R. Yuan, Y. Chai, L. Zhang, N. Wang, and X. Li, "Amperometric third-generation hydrogen peroxide biosensor based on the immobilization of hemoglobin on multiwall carbon nanotubes and gold colloidal nanoparticles," Biosensors and Bioelectronics, vol. 22, no. 7, pp. 1268-1274, 2007.

[10] J. Lin, L. Zhang, and S. Zhang, "Amperometric biosensor based on coentrapment of enzyme and mediator by gold nanoparticles on indium-tin oxide electrode," Analytical Biochemistry, vol. 370, no. 2, pp. 180-185, 2007.

[11] A. Lobnik and M. Čajlaković, "Sol-gel based optical sensor for continuous determination of dissolved hydrogen peroxide," Sensors and Actuators B: Chemical, vol. 74, no. 1-3, pp. 194-199, 2001.

[12] N. V. Klassen, D. Marchington, and H. C. E. McGowan, " $\mathrm{H}_{2} \mathrm{O}_{2}$ determination by the $\mathrm{I}_{3}^{-}$method and by $\mathrm{KMnO}_{4}$ titration," Analytical Chemistry, vol. 66, no. 18, pp. 2921-2925, 1994.

[13] C. T. Kingzett, "LXXIII.-Report on the atmospheric oxidation of phosphorus and some reactions of ozone and hydric peroxide," Journal of the Chemical Society, Transactions, vol. 37, pp. 792-807, 1880.

[14] S. G. Rhee, T.-S. Chang, W. Jeong, and D. Kang, "Methods for detection and measurement of hydrogen peroxide inside and outside of cells," Molecules and Cells, vol. 29, no. 6, pp. 539-549, 2010.

[15] N. Higashi, H. Yokota, S. Hiraki, and Y. Ozaki, "Direct determination of peracetic acid, hydrogen peroxide, and acetic acid in disinfectant solutions by far-ultraviolet absorption spectroscopy," Analytical Chemistry, vol. 77, no. 7, pp. 2272-2277, 2005.

[16] H. Voraberger, V. Ribitsch, M. Janotta, and B. Mizaikoff, "Application of mid-infrared spectroscopy: measuring hydrogen peroxide concentrations in bleaching baths," Applied Spectroscopy, vol. 57, no. 5, pp. 574-579, 2003.

[17] L. Lu, L. Zhang, X. Zhang et al., "A MgO nanoparticles composite matrix-based electrochemical biosensor for hydrogen peroxide with high sensitivity," Electroanalysis, vol. 22, no. 4, pp. 471-477, 2010.

[18] L. Wang and E. Wang, "A novel hydrogen peroxide sensor based on horseradish peroxidase immobilized on colloidal Au modified ITO electrode," Electrochemistry Communications, vol. 6, no. 2, pp. 225-229, 2004.

[19] H. Zhou, X. Gan, J. Wang, X. Zhu, and G. Li, "Hemoglobinbased hydrogen peroxide biosensor tuned by the photovoltaic effect of nano titanium dioxide," Analytical Chemistry, vol. 77, no. 18, pp. 6102-6104, 2005.

[20] X. Zhu, I. Yuri, X. Gan, I. Suzuki, and G. Li, "Electrochemical study of the effect of nano-zinc oxide on microperoxidase and its application to more sensitive hydrogen peroxide biosensor preparation," Biosensors and Bioelectronics, vol. 22, no. 8, pp. 1600-1604, 2007.

[21] H. Y. Shin, T. J. Park, and M. I. Kim, "Recent research trends and future prospects in nanozymes," Journal of Nanomaterials, vol. 2015, Article ID 756278, 11 pages, 2015.

[22] V. G. Gavalas and N. A. Chaniotakis, "Phosphate biosensor based on polyelectrolyte-stabilized pyruvate oxidase," Analytica Chimica Acta, vol. 427, no. 2, pp. 271-277, 2001.

[23] S. N. Azizi, S. Ghasemi, and N. S. Gilani, "Ag-supported nanozeolite L-modified electrode: a new high performance nonenzymatic hydrogen peroxide sensor," Monatshefte für ChemieChemical Monthly, vol. 147, no. 9, pp. 1467-1474, 2016. 
[24] M. Tajabadi, M. Sookhakian, E. Zalnezhad et al., "Electrodeposition of flower-like platinum on electrophoretically grown nitrogen-doped graphene as a highly sensitive electrochemical non-enzymatic biosensor for hydrogen peroxide detection," Applied Surface Science, vol. 386, pp. 418-426, 2016.

[25] C.-L. Sun, J.-S. Su, S.-Y. Lai, and Y.-J. Lu, "Size effects of Pt nanoparticle/graphene composite materials on the electrochemical sensing of hydrogen peroxide," Journal of Nanomaterials, vol. 2015, Article ID 861061, 7 pages, 2015.

[26] K. Liao, P. Mao, Y. Li et al., "A promising method for fabricating Ag nanoparticle modified nonenzyme hydrogen peroxide sensors," Sensors and Actuators, B: Chemical, vol. 181, pp. 125-129, 2013.

[27] Z. Zhu, J. Wang, A. Munir, and H. S. Zhou, "Direct electrochemistry and electrocatalysis of horseradish peroxidase immobilized on bamboo shaped carbon nanotubes/chitosan matrix," Colloids and Surfaces A: Physicochemical and Engineering Aspects, vol. 385, no. 1-3, pp. 91-94, 2011.

[28] J. Zhao, Y. Yan, L. Zhu, X. Li, and G. Li, "An amperometric biosensor for the detection of hydrogen peroxide released from human breast cancer cells," Biosensors and Bioelectronics, vol. 41, pp. 815-819, 2013.

[29] G. I. Berglund, G. H. Carlsson, A. T. Smith, H. Szöke, A. Henriksen, and J. Hajdu, "The catalytic pathway of horseradish peroxidase at high resolution," Nature, vol. 417, no. 6887, pp. 463468, 2002.

[30] E. J. Murphy, C. L. Metcalfe, C. Nnamchi, P. C. E. Moody, and E. L. Raven, "Crystal structure of guaiacol and phenol bound to a heme peroxidase," FEBS Journal, vol. 279, no. 9, pp. 1632-1639, 2012.

[31] D. R. Doerge, R. L. Divi, and M. I. Churchwell, "Identification of the colored guaiacol oxidation product produced by peroxidases," Analytical Biochemistry, vol. 250, no. 1, pp. 10-17, 1997.

[32] N. Mogharrab, H. Ghourchian, and M. Amininasab, "Structural stabilization and functional improvement of horseradish peroxidase upon modification of accessible lysines: experiments and simulation," Biophysical Journal, vol. 92, no. 4, pp. 1192-1203, 2007.

[33] L. Frunza, N. Gheorghe, C. P. Ganea, R. Eckelt, and H. Kosslick, "Oxidation activity of horseradish peroxidase hosted in molecular sieves: spectroscopic investigations show hindering of the enzyme activity," Reaction Kinetics, Mechanisms and Catalysis, vol. 105, no. 1, pp. 195-205, 2012.

[34] D. Sarika, P. S. S. A. Kumar, S. Arshad, and M. K. Sukumaran, "Purification and evaluation of horseradish peroxidase activity," International Journal of Current Microbiology and Applied Sciences, vol. 4, no. 7, pp. 367-375, 2015.

[35] M. J. H. Van Haandel, M. M. J. Claassens, N. Van der Hout, M. G. Boersma, J. Vervoort, and I. M. C. M. Rietjens, "Differential substrate behaviour of phenol and aniline derivatives during conversion by horseradish peroxidase," Biochimica et Biophysica Acta-Protein Structure and Molecular Enzymology, vol. 1435, no. 1-2, pp. 22-29, 1999.

[36] P. Campomanes, U. Rothlisberger, M. Alfonso-Prieto, and C. Rovira, "The Molecular Mechanism of the Catalase-like Activity in Horseradish Peroxidase," Journal of the American Chemical Society, vol. 137, no. 34, pp. 11170-11178, 2015.

[37] D. Linde, R. Pogni, M. Cañellas et al., "Catalytic surface radi$\mathrm{cal}$ in dye-decolorizing peroxidase: A computational, Spectroscopic and Site-directed Mutagenesis Study," Biochemical Journal, vol. 466, pp. 253-262, 2015.
[38] S. Colonna, N. Gaggero, C. Richelmi, and P. Pasta, "Recent biotechnological developments in the use of peroxidases," Trends in Biotechnology, vol. 17, no. 4, pp. 163-168, 1999.

[39] M. Słoma, G. Wróblewski, D. Janczak, and M. Jakubowska, "Transparent electrodes with nanotubes and graphene for printed optoelectronic applications," Journal of Nanomaterials, vol. 2014, Article ID 143094, 7 pages, 2014.

[40] Y.-M. Lee, O.-Y. Kwon, Y.-J. Yoon, and K. Ryu, "Immobilization of horseradish peroxidase on multi-wall carbon nanotubes and its electrochemical properties," Biotechnology Letters, vol. 28, no. 1, pp. 39-43, 2006.

[41] I. Husu, G. Rodio, E. Touloupakis et al., "Insights into photoelectrochemical sensing of herbicides driven by Chlamydomonas reinhardtii cells," Sensors and Actuators, B: Chemical, vol. 185, pp. 321-330, 2013.

[42] J.-L. Huang and Y.-C. Tsai, "Direct electrochemistry and biosensing of hydrogen peroxide of horseradish peroxidase immobilized at multiwalled carbon nanotube/alumina-coated silica nanocomposite modified glassy carbon electrode," Sensors and Actuators B: Chemical, vol. 140, no. 1, pp. 267-272, 2009.

[43] M. Magyar, K. Hajdu, T. Szabó et al., "Sensing hydrogen peroxide by carbon nanotube/horseradish peroxidase bio-nanocomposite," Physica Status Solidi (B) Basic Research, vol. 250, no. 12, pp. 2559-2563, 2013.

[44] L. Nagy, F. Milano, M. Dorogi et al., "Protein/lipid interaction in the bacterial photosynthetic reaction center: phosphatidylcholine and phosphatidylglycerol modify the free energy levels of the quinones," Biochemistry, vol. 43, no. 40, pp. 12913-12923, 2004.

[45] T. Szabó, E. Nyerki, T. Tóth et al., "Generating photocurrent by nanocomposites based on photosynthetic reaction centre protein," Physica Status Solidi B, vol. 252, no. 11, pp. 2614-2619, 2015.

[46] M. Stuiver and H. A. Polach, "Discussion reporting of ${ }^{14} \mathrm{C}$ data," Radiocarbon, vol. 19, no. 3, pp. 355-363, 1977.

[47] M. Molnár, R. Janovics, I. Major et al., "Status report of the new AMS 14C sample preparation lab of the Hertelendi laboratory of environmental studies (Debrecen, Hungary)," Radiocarbon, vol. 55, no. 2-3, pp. 665-676, 2013.

[48] R. Janovics, Development of radiocarbon-based measuring methods and their application for nuclear environmental monitoring [Ph.D. thesis], University of Debrecen and Hungarian Academy of Sciences Institute for Nuclear Research, 2016 (Hungarian).

[49] L. Rinyu, M. Molnár, I. Major et al., "Optimization of sealed tube graphitization method for environmental C-14 studies using MICADAS," Nuclear Instruments and Methods in Physics Research, vol. 294, pp. 270-275, 2013.

[50] H.-A. Synal, M. Döbeli, S. Jacob, M. Stocker, and M. Suter, "Radiocarbon AMS towards its low-energy limits," Nuclear Instruments and Methods in Physics Research, Section B: Beam Interactions with Materials and Atoms, vol. 223-224, pp. 339345, 2004.

[51] H.-A. Synal, M. Stocker, and M. Suter, "MICADAS: a new compact radiocarbon AMS system," Nuclear Instruments and Methods in Physics Research, Section B: Beam Interactions with Materials and Atoms, vol. 259, no. 1, pp. 7-13, 2007.

[52] M. Molnár, L. Rinyu, M. Veres, M. Seiler, L. Wacker, and H.A. Synal, "EnvironMICADAS: a mini 14C AMS with enhanced gas ion source interface in the Hertelendi laboratory of environmental studies (HEKAL), Hungary," Radiocarbon, vol. 55, no. 2-3, pp. 338-344, 2013. 
[53] M. Le Clercq, J. Van Der Plicht, and M. Groning, "New 14C reference materials with activities of 15 and 50 pMC," Radiocarbon, vol. 40, no. 1, pp. 295-297, 1998.

[54] L. Wacker, M. Christl, and H.-A. Synal, "Bats: a new tool for AMS data reduction," Nuclear Instruments and Methods in Physics Research, Section B: Beam Interactions with Materials and Atoms, vol. 268, no. 7-8, pp. 976-979, 2010.

[55] A. El Amrani, F. Hijazi, B. Lucas, J. Bouclé, and M. Aldissi, "Electronic transport and optical properties of thin oxide films," Thin Solid Films, vol. 518, no. 16, pp. 4582-4585, 2010.

[56] H. R. Fallah, M. Ghasemi, A. Hassanzadeh, and H. Steki, "The effect of annealing on structural, electrical and optical properties of nanostructured ITO films prepared by e-beam evaporation," Materials Research Bulletin, vol. 42, no. 3, pp. 487-496, 2007.

[57] S. Luo, K. Okada, S. Kohiki, F. Tsutsui, H. Shimooka, and F. Shoji, "Optical and electrical properties of indium tin oxide thin films sputter-deposited in working gas containing hydrogen without heat treatments," Materials Letters, vol. 63, no. 6-7, pp. 641-643, 2009.

[58] S. Laux, N. Kaiser, A. Zöller, R. Götzelmann, H. Lauth, and H. Bernitzki, "Room-temperature deposition of indium tin oxide thin films with plasma ion-assisted evaporation," Thin Solid Films, vol. 335, no. 1-2, pp. 1-5, 1998.

[59] Y. Li, X. Huang, and Y. Qu, "A strategy for efficient immobilization of laccase and horseradish peroxidase on single-walled carbon nanotubes," Journal of Chemical Technology and Biotechnology, vol. 88, no. 12, pp. 2227-2232, 2013.

[60] S. S. Karajanagi, A. A. Vertegel, R. S. Kane, and J. S. Dordick, "Structure and function of enzymes adsorbed onto singlewalled carbon nanotubes," Langmuir, vol. 20, no. 26, pp. 1159411599, 2004.

[61] P. Asuri, S. S. Bale, R. C. Pangule, D. A. Shah, R. S. Kane, and J. S. Dordick, "Structure, function, and stability of enzymes covalently attached to single-walled carbon nanotubes," Langmuir, vol. 23, no. 24, pp. 12318-12321, 2007.

[62] Z. Wang, M. Li, P. Su et al., "Direct electron transfer of horseradish peroxidase and its electrocatalysis based on carbon nanotube/thionine/gold composites," Electrochemistry Communications, vol. 10, no. 2, pp. 306-310, 2008.

[63] G. J. Maghzal, K.-H. Krause, R. Stocker, and V. Jaquet, “Detection of reactive oxygen species derived from the family of NOX NADPH oxidases," Free Radical Biology and Medicine, vol. 53, no. 10, pp. 1903-1918, 2012.

[64] M. B. Grisham, "Methods to detect hydrogen peroxide in living cells: possibilities and pitfalls," Comparative Biochemistry and Physiology-A Molecular and Integrative Physiology, vol. 165, no. 4, pp. 429-438, 2013. 

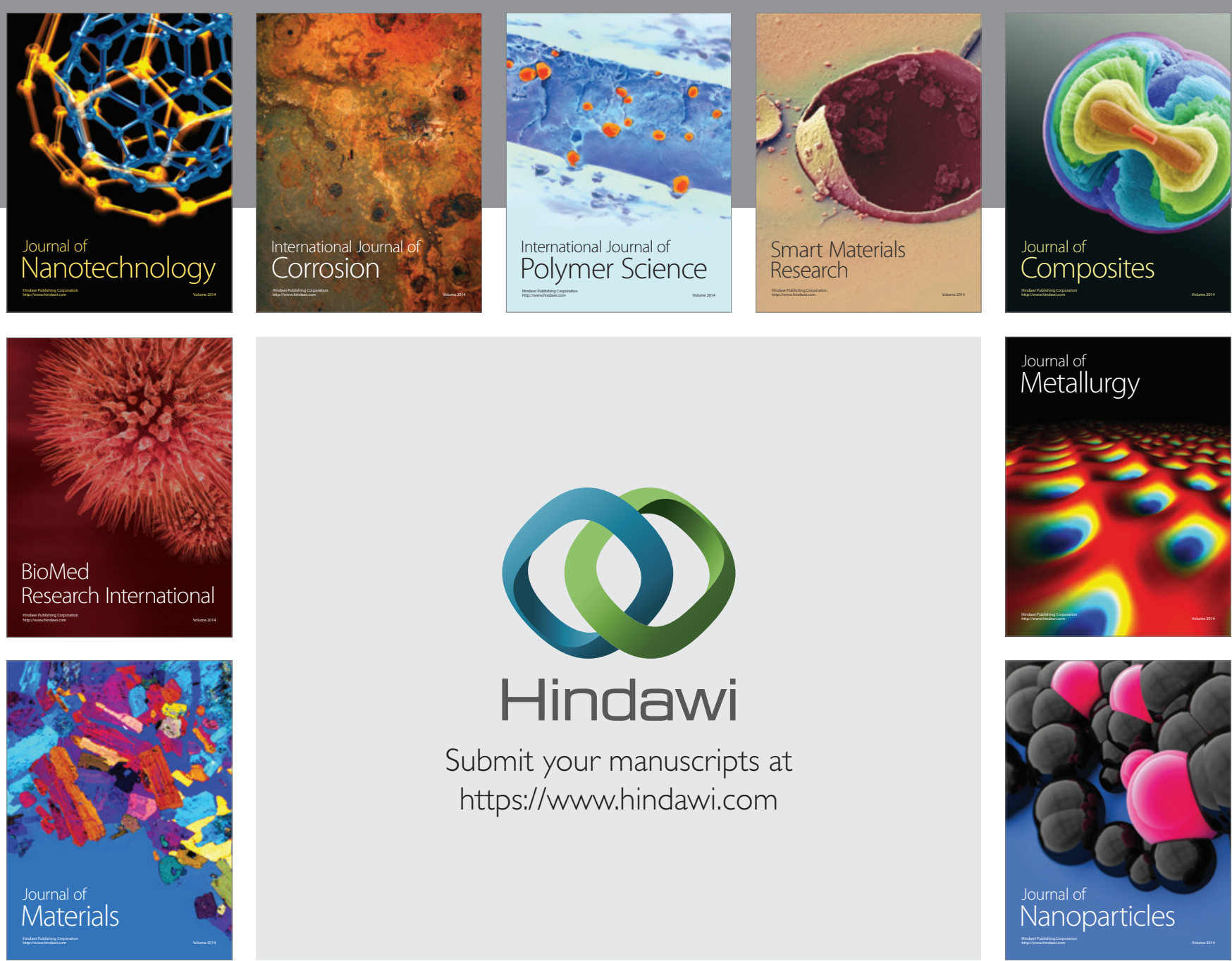

\section{Hindawi}

Submit your manuscripts at

https://www.hindawi.com

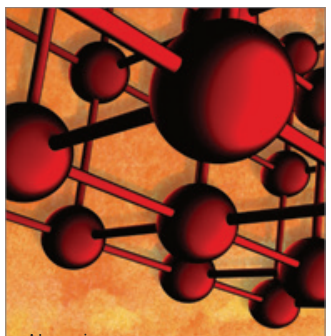

Materials Science and Engineering
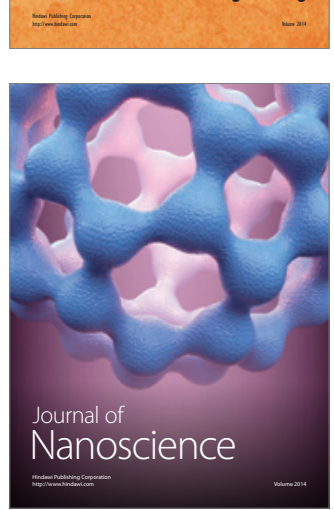
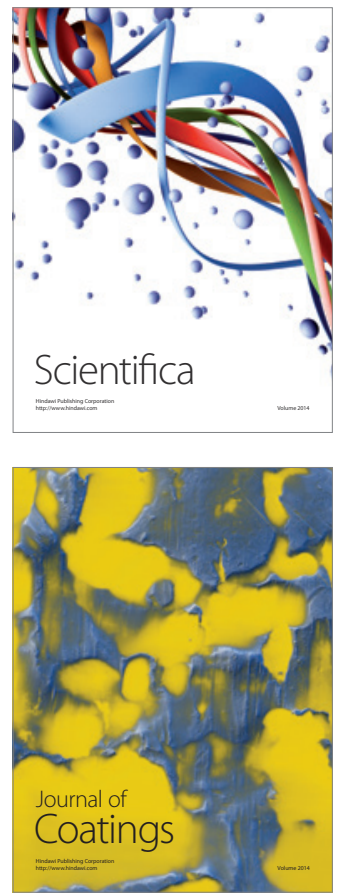
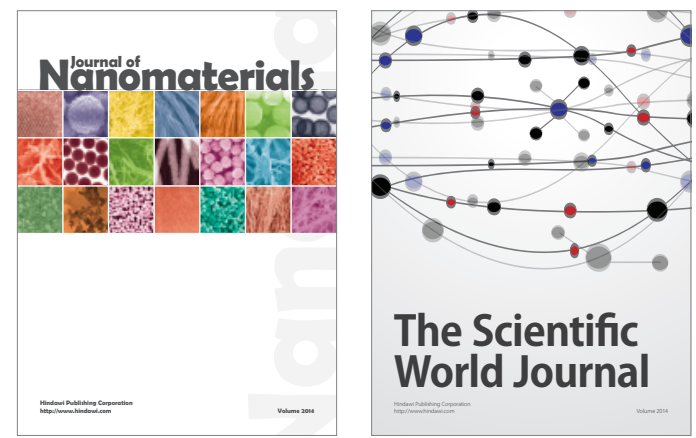

The Scientific World Journal
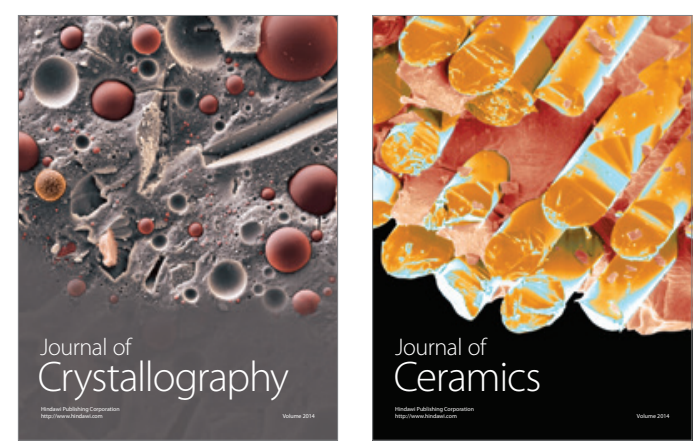
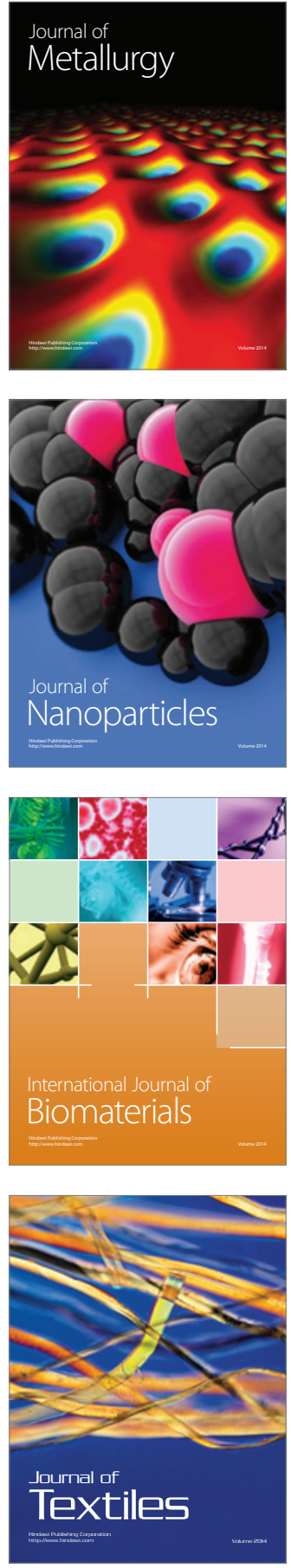